\title{
The Protection of Linguistic Minorities: An Appraisal on the Role of Multination Federalism
}

\author{
Amare Tesfaye, Zelalem Kebu \\ Law School, Dilla University, Dilla, Ethiopia \\ Email: amaretsf76@gmail.com,zolabekele@gmail.com
}

How to cite this paper: Tesfaye, A., \& Kebu Z. (2016). The Protection of Linguistic Minorities: An Appraisal on the Role of Multination Federalism. Beijing Law Review, 7, 314-333.

http://dx.doi.org/10.4236/blr.2016.74028

Received: October 7, 2016

Accepted: December 24, 2016

Published: December 27, 2016

Copyright $\odot 2016$ by authors and Scientific Research Publishing Inc. This work is licensed under the Creative Commons Attribution International License (CC BY 4.0).

http://creativecommons.org/licenses/by/4.0/

\begin{abstract}
This article mainly focuses on the role of multination federalism in protecting linguistic minorities from assimilation or crumbling to/from the majority in a multination federacy like Ethiopia. In doing so, it has attempted to reflect the concerns raised by some other scholars in relation to territorial integrity of the state in a multination federal state structure and a conclusion as to the inappropriateness of such concern has been reached exhaustively. Resultantly, this article argues that multination federalism is highly potent to maintain integrity of the state, resolving the void by filling it against the possible tensions that may exist between the linguistic minorities and majorities. It has subtle fortitude for the protection of linguistic minorities among others through exactitude of the schemes like conferring them distinctive autonomy within a multination state, igniting them to employ their language without any encroachment and epithet, ensuring them to deserve their distinct identity and paving the way to ensure their participation in different fields meant for the public concerns. It also attracts the linguistic minorities' right to education in their own mother tongue.
\end{abstract}

\section{Keywords}

Assimilation, Linguistic Minorities, Multination Federalism, Rights of Minorities, Territorial Integrity

\section{The Milieu Remarks on Minority}

Historically speaking, the discourse of minorities was intimately linked to the self-determination of peoples (Musgrave, 1997). States are reluctant to acknowledge rights of minorities because they try to avoid risks for their territorial integrity. The fight of minorities for their rights has given rise to armed conflicts. These dangers and experiences 
made minority protection one of the most complex and complicated themes of international law. There have been many political discussions in numerous international organizations, especially in the UN. Consequently, different treaties and institutions have been created in order to organize the protection of minorities. The protection of minorities is an integral part of the protection of human rights in modern international law (Kugelmann, 2007). The struggle for individual human rights also concerns the grapple for the individual rights of persons belonging to a minority. The very special approach of minority protection is linked with the more general quandary of the right of groups (Riker, 1964).

Aftermath of WW I, two tremendous developments are deemed to have emerged to look into the other side of the World to safeguard the global peace: The peace treaties concluded then included a number of provisions aiming to protect the rights of minorities and the coming in to picture of Permanent Court of International Justice that has also identified the two crucial points of minority protection in its Advisory Opinion on minority schools in Albania ${ }^{1}$,

The first is to ensure that nationals belonging to racial, religious or linguistic minorities shall be placed in every respect on a footing of perfect equality with the other nationals of the State. The second is to ensure for the minority elements suitable means for the preservation of their racial peculiarities, their traditions and their national characteristics.

The other aspect can be seen nowadays as part of the discussion on autonomy and diversity in a society. The growing importance of the subject of cultural diversity is linked to the status and role of groups in a state and those groups may be minorities (Cf. Palermo \& Woelk, 2003/4). The law of minority protection is intertwined with the historical and sociological backgrounds of each situation. Demographic change influences as one factor of the protection of minorities because a minority may become a majority or migration may be accelerated (Wiessner, 2005). Therefore, anthropological, philosophical and sociological reasons are part of the legal reasoning in cases of minority protection. An interdisciplinary approach is necessary, otherwise, conflicts arising because of the diversity of cultures and nations cannot be solved (Bommes \& Morawska, 2005).

Quite spaced out even from the question whether the peace treaties concluded after the WW I still were binding after the WW II, the idea prevailed in 1945/6 that the protection of minorities had failed to mollify the relationships between States (particularly States where national minorities are located and their kin-States), and that it would become unnecessary in light of the emergence of an international protection of human rights (Simpson, 2001). An increasingly capacious body of jurisprudence has emerged from human rights bodies that protect minorities through human rights such as the right to respect for private life, freedom of religion, the right to education, or the right

${ }^{1}$ Permanent Court of International Justice (1935), Minority Schools in Albania (Greece vs. Albania), Orders and Advisory Opinion, P.C.I.J., Series A/B, Judgements No. 64, Para 4.17. 
to property, either alone or in combination with the requirement of non-discri-mination. It would hardly be an embellishment to say that human rights have legitimized and made politically acceptable a revival of minority rights that minority rights have re-entered the field of international law through the canal of human rights protection (Dinstein \& Tabory, 1992; Rehman, 2000; Thornberry, 1991). For instance, indigenous peoples may rely on article 27 to defend their way of life and the specific characteristics of their group. The international protection of minorities works on solid grounds. It may be influenced by the concept of "cultural diversity" insofar as the interpretations of notions like "culture" in article 27 ICCPR may undergo a progressive evolution. As the general concept of "cultural diversity" is not yet clear, the protection of minorities should not be subject to far reaching changes as long as the direction of the changes cannot be identified. The instruments on minorities have not been modified but the existing instruments at least grant a safe standard of protection under international law.

Cautious modifications may refer to the application of the existing provisions. Recent international documents suggest a system of gradual protection. The Commentary to the Declaration on the Rights of Persons belonging to National or Ethnic, Religious and Linguistic Minorities (1992) ${ }^{2}$ includes all relevant groups in the international protection of minorities but tends to grant more rights to "old" minorities. However, according to these ideas new minorities fall under the minority protection of international law. This extension of the scope of minority protection works only on the basis of an individual human rights approach. There will be a reluctance of states to accept the concept of conferring rights to further groups if these rights can be interpreted as collective rights for the group. Different minorities have different kinds of needs and claim different rights.

This being so, looking another side of facts on the ground from the Governance System prospective the paradox resides in the umbilical cord of successful accommodation of difference and diversity that create a novel state but that also create the conditions for both a stable and an unstable state at the same time. It is surely a curious set of circumstances that lead to the formation of a federation founded upon strong cultural ideological differences deliberately, such as distinct nations, which will always constitute one of the major blunder lines in its subsequent evolution. Together, these eminent contributors to the early debate about multinational federalism had called attention to several important features and characteristics of complex federal state formation that would later take the form of stresses, strains and tensions built into the experiment from its inception. In short, they pointed to a variety of paradoxes, pitfalls and dangers that would threaten such a federation from the moment it was launched. It was asking for trouble. Why, then, would political elites champion such a hazardous enterprise? What peculiar circumstances would have to exist in order to create a set of conditions conducive to multinational federalism, that is, the desire and willingness of such dis-

${ }^{2}$ Declaration on the Rights of Persons Belonging to National or Ethnic, Religious and Linguistic Minorities, A/RES/47/135 of 18 December 1992, Doc. E/CN.4/AC.5/2001/2. 
tinct identities to live together in the same federal state? That be what it may, this article is commemorated to scrutinize the correlation of protecting linguistic minorities and multination federalism thoroughly; their examination in terms of role of the latter in engulfing various diversities in a unity at once, in the process of constructing stable federacy for the state of common.

\section{Who Are Minorities?}

There is no internationally agreed definition as to which groups constitute minorities unequivocally. It is often stressed that the existence of a minority is a question of fact and that any definition must include both objective factors (such as the existence of a shared ethnicity, language or religion) and subjective factors (including that individuals must identify themselves as members of a minority). The mystique in arriving at a widely acceptable definition lies in the variety of situations in which minorities live. Some live together in well-defined areas, separated from the dominant part of the population. Others are scattered here and there throughout the country haphazardly. Some minorities have a strong sense of collective identity and recorded history; others retain only a fragmented notion of their common heritage.

The term minority as used in the UN human rights system usually refers to national or ethnic, religious and linguistic minorities, pursuant to the UN Minorities Declaration. All States have one or more minority groups within their national territories, characterized by their own national, ethnic, linguistic or religious identity, which differs from that of the majority population. The 1992 UN Declaration on the Rights of Persons Belonging to National or Ethnic, Religious and Linguistic Minorities (UNDM) was inspired by Article 27 of the ICCPR, which states:

In those States in which ethnic, religious or linguistic minorities exist, persons belonging to such minorities shall not be denied the right, in community with the other members of their group, to enjoy their own culture, to profess and practice their own religion, or to use their own language.

Despite the references to minorities found in international legal instruments ${ }^{3}$, there is still no definition of minorities likely to command general approval. Indeed, it is often postulated that there is little need for a single definition, which could bear out unnecessarily limiting. The UN Special Rapporteur Capotorti (1966) proposed the following definition in the context of Article 27 of the ICCPR:

A group numerically inferior to the rest of the population of a State, and in a nondominant position, whose members being nationals of the State possess ethnic, religious or linguistic characteristics differing from those of the rest of the population and show, if only implicitly, a sense of solidarity, directed towards preserving their culture, traditions, religions and language (Capotorti, 1991).

${ }^{3}$ It should be noted that internationally the minority rights language emphasizes the rights of individuals in community with others as opposed to the rights of groups per se. However, as shown by the Human Rights Committee's jurisprudence, there is no objection to a group of individuals who claim to be commonly affected submitting a communication about alleged breaches of their rights under the ICCPR. 
While the nationality criterion included in the above definition has often been challenged, the requirement to be in a non-dominant position remains important. In most instances, a minority group will be a numerical minority, but in others a numerical majority may also find itself in a minority like or non-dominant position, such as Blacks under the apartheid regime in South Africa. In some situations, a group which constitutes a majority in a State as a whole may be in a non-dominant position within a particular region of the State in question. In addition, it has been argued that the use of subjective criteria, such as the will on the part of the members of the groups in question to preserve their own characteristics and the wish of the individuals concerned to be considered part of that group, combined with certain specific objective requirements, such as those listed in the Capotorti definition, should be taken into account. It is now commonly accepted that recognition of minority status is not solely for the State to decide, but should be based on both objective and subjective criteria.

The question often arises as to whether, for example, persons with disabilities, persons belonging to certain political groups or persons with a particular sexual orientation or identity (lesbian, gay, bisexual, transgender or intersexual persons) constitute minorities. While the UN Minorities Declaration is devoted to national, ethnic, religious and linguistic minorities, it is also important to combat multiple discrimination and to address situations where a person belonging to a national or ethnic, religious and linguistic minority is also discriminated against on other grounds such as gender, disability or sexual orientation. Similarly, it is important to keep in mind that, in many countries, minorities are often found to be among the most marginalized groups in a society and severely affected by, for example, pandemic diseases, such as HIV/AIDS, and in general have limited access to health services.

A refinement of this definition was proposed in 1985 by Jules Deschênes, again at the request of the UN Sub-Commission, which states:

A group of citizens of a State, constituting a numerical minority and in a non-dominant position in that State, endowed with ethnic, religious or linguistic characteristics which differ from those of the majority of the population, having a sense of solidarity with one another, motivated, if only implicitly, by a collective will to survive and whose aim is to achieve equality with the majority in fact and in law (Deschênes, 1985).

While both definitions contribute to an understanding of the concept of minorities, they are not without their difficulties. For example, the criterion of numerical minority is not entirely satisfactory where there may be no clear numerical minority or majority. And, indeed, a distinct ethnic group can constitute a numerical majority and be in a non-dominant position and, thus, be similarly entitled to the application of many minority standards in order to ensure their rights to non-discrimination and protection of their identity which form the foundations of minority rights. The limiting criterion of citizenship can also be used to exclude certain groups from their rights as minorities and has in fact not been accepted as a defining minority characteristic. In this regard, the UN Human Rights Committee (HRC) has stated in a General Comment to Article 27 of the ICCPR that a State party may not restrict the rights under Article 27 to its cit- 
izens alone $e^{4}$. To this may be added the important point referred to by the HRC that:

the existence of an ethnic, religious or linguistic minority in a given State party does not depend upon a decision by that State party but requires to be established by objective criteria ${ }^{5}$.

This is ascetically linked to self identification in determining minority status. Any definitional criteria should aim at the furtherance of the rights of minorities to exist, to be treated without discrimination, to the preservation of their cultural identity and to their participation in public life.

\section{The Continent-Specific Conception of Minority in Africa}

The ethnic oeuvre of African states is complex and the question of minority status, especially in terms of the non-dominance of particular groups, is complicated by the way in which political elites have exploited ethnic or religious differences for political ends. In practice, some numerically smaller groups, through alliances with other groups, may exert political dominance. This is the case, for example, in Nigeria where historically dominant minorities such as the Efik or the Ijaw finds themselves now marginalized politically. However, changes in the political kismets of these alliances may change the situation of an ethnic group from a position in which they have access to power to that of a non-dominant status. There are also examples in Africa, where numerically large groups the Hutu in Rwanda or the Oromo in Ethiopia have been largely excluded from power. This is further complicated by the fact that many ethnic groups in Africa have traditional economic or social interactions with neighbouring peoples that may be the basis of political rivalries or alliances depending on circumstances.

Another issue is the denial of citizenship to particular groups. Indeed, despite the fact that the right to a nationality is a well-established tenet of international law ${ }^{6}$, the question of citizenship continues to be a major concern in Africa and is linked to participation in public life or access to lands, as is the case in the Democratic Republic of Congo, Kenya, Zambia and Côte d'Ivoire (Singo'ei, 2003). To provide some general guidance on who constitutes minorities in Africa in line with international norms, the following elements could be considered:

1) any ethnic, linguistic or religious group within a state,

2) in a non-dominant position in the state in which they live,

${ }^{4}$ HRC General Comment No. 23, 50 ${ }^{\text {th }}$ session, states (1994): "the terms used in article 27 indicate that the persons designed to be protected are those who belong to a group and who share in common a culture. a religion and/or a language. Those terms also indicate that the individuals designed to be protected need not be citizens of the State party. In this regard. the obligations deriving from article 2 (1) are also relevant. since a State party is required under that article to ensure that the rights protected under the Covenant are available to all individuals within its territory and subject to its jurisdiction. ...”. (Para 5.1)

${ }^{5}$ Ibid, 149 states are party to the ICCPR as of 9 December 2002. Almost all African states are party (except Comoros, Mauritania and Swaziland). (Para. 5.2)

${ }^{6}$ UDHR (1948), Adopted by the General Assembly of the UN, Resolution 217 (III) of 10 December 1948, article 15; ICESCR (1976), Adopted and opened for signature ratification and accession by the General Assembly of the UN, Resolution 2200 XXI of 16 December 1966: Entry into force on 3 January 1976, Article 24 (3) and Convention on the Rights of the Child (1989), Adopted by the UN General Assembly in resolution No. 44/25 of 20 November 1989 at New York: Entered into force on 2 September 1990, Article 7. 
3) consisting of individuals who possess a sense of belonging to that group,

4) determined to preserve and develop their distinct ethnic identity and

5) discriminated against or marginalized on the grounds of their ethnicity, language or religion.

To begin with, recognition of minorities would lead to achieving the aims of preserving their identities and of obtaining equality with all other groups in that state, including in relation to participation in political life as well as in development matters. There are many ethnic groups to which these elements would apply, although they may or may not identify themselves as minorities, for example: the Bakilayi and Karimajong in Uganda, the Ijaw and Ogoni in the Rivers State of Nigeria, the Wayeyi, Bakalaka and Bakgaladi in Botswana, the Herero in Angola, the Konkomba in Ghana, the Twa in Burundi, the Bakweri and Bagyeli in Cameroun, the Sengwer, Maasai and Ogiek in Kenya, the Haratin and Black Africans in Mauritania, the Afar in Djibouti, the Khoisan in South Africa (Ibid).

\section{The Criterion of Self-Identification}

The key criterion that is increasingly accepted internationally in the determination of minority status is that of self-identification. On this basis, it is the individuals and, thus, groups themselves who should self identify as minorities, irrespective of whether they are described as nationalities, communities, ethnic groups, peoples or nations by states. Notably, self identification is also central to identification as an indigenous people, as can be seen, for example, in article 1 (2) of the International Labour Organization's Convention No. 169 Concerning Indigenous and Tribal Peoples in Independent Countries $^{7}$, and in the Committee on the Elimination of Racial Discrimination's General Recommendation VIII ${ }^{8}$. Although, at the international level, indigenous peoples often feel it to be important to emphasize their differences with minorities, and, therefore, to defend their need for separate standards under international law, in the African context indigenous peoples or ethnic communities often adopt a more flexible approach'. The international standards in place to protect and promote the rights of indigenous peoples aim to address and redress the particular forms of abuses and violations that they are likely to suffer. Significantly, however, minorities who may not self-identify as indigenous may also have similar legitimate claims regarding their relationships to land (Plant, 1994) and with regard to their demands for autonomy ${ }^{10}$, and this is equally the

${ }^{7}$ ILO Convention concerning Indigenous and Tribal Peoples in independent countries (ILO Convention No. 169 ILO official Bulletin 59), Entered in to force 5 September 1991, article 1 (2), "Self-identification as indigenous or tribal shall be regarded as a fundamental criterion for determining the groups to which the provisions of this Convention apply."

8" The Committee on the Elimination of Racial Discrimination, Having considered reports from States Parties concerning information about the ways in which individuals are indentified as being members of a particular racial or ethnic group has of the opinion that such identification shall, if no justification exists to the contrary, be based upon self-identification by the individual concerned." $\left(38^{\text {th }}\right.$ session, 1990).

${ }^{9}$ Many ethnic groups in Africa describe themselves as indigenous minorities. The names of their organizations also reflect that particularity, for example, the Working Group on Indigenous Minorities in Southern Africa (WIMSA), the African Indigenous and Minority Peoples Organization (AIMPO) in Rwanda, etc. ${ }^{10} \mathrm{P}$. Leuprecht (2001), Minority Rights Revisited, in P. Alston (ed.), Peoples Rights, Oxford, Oxford University Press. 
case in Africa.

The African Commission on Human and Peoples' Rights (ACHPR) adopted a Resolution on the Rights of Indigenous Peoples/Communities in Africa in $2000^{11}$ in which it decided:

to establish a working group of experts on the rights of indigenous peoples or ethnic communities in Africa' with the mandate "to examine the concept of indigenous peoples and communities in Africa" and: "...study the implications of the African Charter on Human Rights and well being of indigenous communities especially with regard to the right to equality (article 2 and 3), the right to dignity (article 5), the protection against domination (article 19), self-determination (article 20), the promotion of cultural development and identity" (article 22).

This is a welcome advance that could do much to strengthen the application of international standards in the region.

As far as linguistic minority is concerned, on top of this, Joseph Gromacki defined language in the matter under consideration as "language is intrinsically linked to the development of both an individual human consciousness and a sense of group or cultural identity" (Joseph, 1991). Gromacki then goes even further into showing the importance of language for culture and general idea of human rights "...the protection of linguistic rights becomes essential to the protection of human dignity" (Ibid).

It is a very important observation as it puts language as one of the most important factors within culture and human dignity. Minorities are also traditionally (although still controversially) defined as a group of persons who reside on the territory of a State and are citizens thereof, display distinctive ethnic, cultural, religious or linguistic characteristics, are smaller in number than the rest of the population of that State or of a region of that State, and are motivated by a concern to preserve together that which constitutes their common identity, including their culture, their traditions, their religion or their language ${ }^{12}$. But, there has been a proclivity, particularly within the Human Rights Committee (in its interpretation of article 27 of the ICCPR) and within the Advisory Committee established under the Framework Convention for the Protection of National Minorities, to augment the scope of the provisions protecting minority rights, so as to ensure that "minority rights" benefit all those under the jurisdiction of the State, who present certain discrete characteristics.

This fruition would result in defining minority rights as human rights so as in prin-

${ }^{11}$ The Resolution was adopted at the $28^{\text {th }}$ Ordinary Session of the African Commission, 23 October to 6 November 2000. The Working Group of experts held its first meeting prior to the $30^{\text {th }}$ Ordinary Session of the African Commission on 12 October 2001 in Banjul, The Gambia. As a follow-up to this meeting, members of the Working Group drafted a Conceptual Framework Paper to map out the scope of what the Working Group would seek to address. This Conceptual Framework Paper was discussed at a Roundtable that was held prior to the $31^{\text {st }}$ Ordinary Session of the African Commission on 30 April 2002 in Pretoria, South Africa. Indigenous representatives and experts on indigenous issues in Africa contributed to the discussion. Another consultative meeting took place in Nairobi, Kenya, in February 2003.

${ }^{12}$ Recommendation 1201 (1993) adopted by the Parliamentary Assembly of the Council of Europe, proposing the adoption of an Additional Protocol on the Rights of National Minorities to the European Convention on Human Rights (F. Capotorti, 1991) and EU Network of Independent Experts on Fundamental Rights (2005), Thematic Comment No. 3, The Protection of Minorities in the European Union, 25 April 2005, Para 1.1. 
ciple to be enjoyed by all, whether or not they are found to belong to a "minority" under the conventional definition of the terminology. This predilection has been strongly criticized by certain States. Germany, for example, argues that:

"The objective of the Framework Convention [for the protection of national minorities] is to protect national minorities, it is not a general human rights instrument for all groups of the population which differ from the majority population in one or several respects (ancestry, race, language, culture, homeland, origin, nationality, creed, religious or political beliefs, sexual preferences, etc.), the members of the latter groups are protected by the general human rights and if they are nationals by the guaranteed civil rights" ${ }^{\prime 3}$.

One is led to ask, though, why this opposition is so heated, if indeed, those groups the "non-minorities" who differ through one or more characteristics from the majority anyway are protected under human rights that largely ensure the same protection of diversity within increasingly multicultural societies. The convergence is such, between minority rights and human rights, that the former have largely lost their treasonable character: it is their distinctiveness that they are now in pain in the neck of losing.

\section{The Protection of Minority Rights}

Arguably, there are three methods through which minority rights can be protected under human rights systems (Scheinin \& Toivanen, 2004). At the first place, whether they are ethnic, linguistic, religious or cultural, minorities can be protected through the wide-ranging prohibition of non-discrimination i.e. through scion and discharge of genuine equality across the board predominantly. Minorities can be protected through other human rights provisions, such as freedom of religion, freedom of association or the right to respect for private life, secondly. Finally, at the third place, the right of minorities "to enjoy their own culture, to profess and practice their own religion, or to use their own language", can be protected as such, under article 27 of the ICCPR: although this provision refers to the "persons belonging to minorities" as the rights-holders; it, nevertheless, begins with the recognition that such rights matter because of the existence of minorities under the State's jurisdiction. This latter form of protection may be called "direct", since it refers explicitly to the rights of minorities rather than "indirectly" allowing for members of minority groups to exercise their individual rights collectively.

The boundaries between these different techniques of protection are sometimes blurred: for instance, the right to respect for private life has occasionally been read as providing, in substance, a protection similar to that of article 27 of ICCPR. These approaches may of course be combined, as they are under the ICCPR. By the same token, under the Council of Europe Framework Convention for the Protection of National Minorities adopted in 1995, the parties not only undertake to "promote the conditions necessary for persons belonging to national minorities to maintain and develop their culture, and to preserve the essential elements of their identity, namely their religion,

\footnotetext{
${ }^{13}$ Germany (2009), Third State Report, ACFC/SR/III (2009)003, Para. 8.
} 
language, traditions and cultural heritage" and to "refrain from policies or practices aimed at assimilation of persons belonging to national minorities against their will and shall protect these persons from any action aimed at such assimilation" (article 5), they also commit to "guarantee to persons belonging to national minorities the right of equality before the law and of equal protection of the law" and to prohibit discrimination (article 4 (1)) as well as to "ensure respect for the right of every person belonging to a national minority to freedom of peaceful assembly, freedom of association, freedom of expression, and freedom of thought, conscience and religion" (article 7). Provided that the potential of the non-discrimination provisions contained in international human rights instruments has been explored herein above; the two other routes through which the rights of minorities or of persons belonging to minorities can be protected are digested herein below.

\subsection{The Direct Itinerary}

This refers to the explicit protection of rights of minorities. According to article 27 ICCPR, "those States in which ethnic, religious or linguistic minorities exist, persons belonging to such minorities shall not be denied the right, in community with the other members of their group, to enjoy their own culture, to profess and practise their own religion, or to use their own language." In line with this, claims based on the right to self-determination may occasionally also raise issues which concern the protection of minority rights ${ }^{14}$.

\subsection{The Indirect Itinerary}

This refers to the protection of the rights of minorities and the right to respect for private and family life. A broad understanding of the requirements of the right to respect for private life have allowed human rights bodies to protect minority rights even where a State denies that minorities exist under its jurisdiction, or in the absence of a specific clause relating to such rights. In the decision, it adopted in the Hopu and Bessert case, the Human Rights Committee while accepting that it is not competent to assess whether France has complied with article 27 ICCPR, due to a declaration by France that this provision did not apply to it protects the rights of indigenous peoples by relying on the definition of "family" it offered in its General Comment No. 16 (1988) where it stated that "regarding the term 'family' [which appears in article 17 ICCPR], the objectives of the Covenant require that for the purposes of article 17 this term be given a broad interpretation to include all those comprising the family as understood in the society of the State party concerned"15.

\footnotetext{
${ }^{14}$ Human Rights Committee, Concluding Observations: Canada (CCPR/C/CAN/CO/5, 20 April 2006), Para 8 - 10; Human Rights Committee, Chief Bernard Ominayak and the Lubicon Lake Band vs. Canada, Communication No. 167/1984 (UN Doc. Supp. No. 40 (A/45/40), p. 1), final views of 26 March 1990; Human Rights Committee, Ballantyne, Davidson, McIntyre vs. Canada, Communications Nos. 359/1989 and 385/ 1989 (CCPR/C/47/D/359/1989 and 385/1989/Rev.1 (1993)), final views of 31 March 1993 and Human Rights Committee, The Rights of Minorities, General Comment No. 23, Art. 27) (CCPR/C/21/Rev.1/Add. 5) (8 April 1994).

${ }^{15}$ Human Rights Committee, Hopu and Bessert vs. France, Communication No. 549/1993 (CCPR/C/60/D/ 549/1993/Rev.1), final views of 29 July 1997, Para. 5.
} 
An early decision of the European Court of Human Rights was Noack and others vs. Germany $^{16}$, which concerned the transfer scheduled to take place at the end of 2002 of the inhabitants of Horno, a village in the Land of Brandenburg near the Polish border. Horno has a population of 350, approximately a third of whom are from the Sorbian minority, of Slav origin. Approximately 20,000 Sorbs (Sorben) live in the Land of Brandenburg. They have their own language and culture. The inhabitants of Horno were to be transferred to a town some twenty kilometres away because of an expansion of lignite mining operations in the area. The Court noted that "for the purposes of article 8 of the Convention, a minority's way of life is, in principle, entitled to the protection guaranteed for an individual $s$ private life, family life and home"17. Independently of the issue of the protection of minority rights those of the Sorbs in this instance the Court considers that transferring the population of a village raises a problem under article 8 of the Convention, since it directly concerns the private lives and homes of the people concerned.' The position according to which article 8 ECHR protects the rights of minorities was made explicit ${ }^{18}$.

\section{The Deliberations on Federalism ${ }^{19}$}

Before dealing with the concept of federalism, it is essential to understand what a federation means. Accordingly, the term federation is derived from Latin word foedus

${ }^{16} \mathrm{Ibid}$, Application No. 46346/99, decision (inadmissibility) of 25 May 2000.

${ }^{17}$ G. and E. vs. Norway, Applications Nos. 9278/81 and 9415/81, decision of the Commission of 3 October 1983, DR 35, p. 30; and Buckleyvs. United Kingdom, Application No. 20348/92, report of the Commission of 11 January 1995, p. 64; and Chapman vs. United Kingdom, Application No. 27238/95, report of the Commission of 25 October 1999, p. 65.

${ }^{18}$ European Court of Human Rights (GC), Chapman vs. United Kingdom, (Appl. No. 27238/95), judgment of 18 January 2001.

${ }^{19}$ Federalism is an organizational principle for a common entity consisting of parts which comprise equal, more or less independent members; Federal State is an alliance of non-sovereign states which are connected with each other by a contract on the alliance. Here, sovereignty under international public law is given only with the superordinated central state. The Federal Republic of Germany, the USA and Switzerland are federal states; Association/Union of States, i.e. confederation, is an alliance of sovereign states that originated from an International Law Treaty. The federal (member) states remain sovereign in the sense of international public law. However, they use common bodies for the purpose of solution of common tasks. Examples for associations of states are, for instance, the Commonwealth of Independent States (CIS), or the German Federation of 1815-1866. Unitary State is the political counter principle to federalism. In a Unitary State, the state power is limited to some central institutions. There is no regionalization with political independence; consequently there are no Member States or single states. Examples for this are France, Italy or the former German Democratic Republic. Republic (the term is derived from the Latin term res publica), describing a freely modelled entity, founded on the basis of the approval of the peoples of this state. The term originated in the $18^{\text {th }}$ and $19^{\text {th }}$ century in order to delimit the "free people's state" from a monarchy. In Centralism, the supreme state authorities decide on state functions down to the last detail, while the subordinated governments then execute these, without any leeway. The principle of Decentralization states that governmental decisions shall be taken by state authorities only in principle. Further execution of these takes place by subordinated bodies and self-administered communities. Unitarism is, like the concept of centralism, an organizational standardization within a country. Unitarization describes the endeavour to establish an organizational standardization within the framework of a state. Regionalism or Regionalization is to be considered in the context of the term of region. A region is a district which due to its historical, ethnic, cultural or regional common characteristics of its population is regarded as a unity. Sovereignty means actually the supreme power, and this can be legally effective both internally and externally. External sovereignty means the state's independence from all other states and international organizations. 
meaning pact, alliance, covenant or an arrangement entered into voluntarily and implying a degree of mutual trust and duration (Dosenrode, 2010). For Daniel Elazar, "federal principles are concerned with the combination of self-rule and shared rule (Ibid)." Thus, what differentiates it from Unitary States is that it consists of two or more levels of government: a number of member states each with their government and the totality of the member states with its federal government (Ibid). King defines a federation as "an institutional arrangement, taking the form of a sovereign state, and distinguished from other such states solely by the fact that its central government incorporates regional units in its decision procedure on some constitutionally entrenched basis (Ibid)." Similarly, Burgess states that "federation is a specific organizational form which includes structures, institutions, procedures and techniques. It is a tangible institutional reality. And it can be distinguished from other forms of state relatively clearly (Ibid)."

Federations may be organized very differently. Taking a power perspective, they may be peripheral, where the states are strong with many competencies, or they may be centralized, where the federal government has the predominant say (Ibid). Looking at their internal structure Burgess distinguishes between the Westminster model (e.g. Canada), the republican-presidential model (e.g. USA) and hybrids of the two (e.g. Germany) (Ibid). Federalism is the process leading or attempting to lead to a state of federation and is in this sense a normative, ideological approach, and Elazar points to the confusing fact that federalism is both the process and structure (Ibid). Burgess describes the process of federalism as:

It is ideological in the sense that it can take the form of an overtly prescriptive guide to action, and it is philosophical to the extent that it is a normative judgment upon the ideal organization of human relations and conduct (Ibid).

\section{Multination Federalism Circle of Basic Concepts}

Unlike nation state federalism, diversified nations and multitudes at the same time directly touching up on the intrinsic essentials of their identity are there in a multination federalism. Homogeneity is the peculiarity in case of the former whereas the reverse, which is heterogeneous constituents are characterizing the latter one (International Crisis Group, 2009). During the $18^{\text {th }}$ and $19^{\text {th }}$ centuries in particular, the establishment of standardised national languages and universal education, the press and publication of books in these languages, followed the idea of the French Revolution "one state-one nation-one language" (Trim, 2002). In more recent times, language has often been used as an instrument for enforcing nationalism and is seen as the cause for ethnic disputes resulting in intolerance and conflict. Policy makers often see multilingualism as a divisive, inefficient, useless and expensive force. As a result of this, federal systems face a number of discrete threats, which can be summarized as either belonging to disintegration as a result of irrelevancy or separation because of political antagonization or, perhaps the worst scenario, prolonged political dysfunctionality. Assuming the classical readings are right, and the solutions are, thus, at the core Constitutional, such must 
surely reflect itself in how some of the world's recently formed multiethnic federations have written and implemented their Constitutions. In this light, the federal imperative was not only essentially a compromise, but it was also construed as a last resort. In other words, it was couched in terms of stark alternatives: "federate or separate" (Trudeau, 1968). Multinational federalism, then, conveyed a sense of "separateness" within the state rather than separation from the state. It presumed the protection, preservation and promotion of distinct sub-state nations that would be able to determine themselves as nations within the larger federal state. This is, in turn, meant that multinational federation would be ipso facto predicated upon the notion of a vibrant multinational federalism and that this would be its principal purpose as a state. In this case, an example would be the Constitution of the post-1995 Federal Democratic Republic of Ethiopia, which addresses ethno-national minority rights in Chapter 3, Articles 13 - 44 and Article $39^{20}$ (a fully fledged Bill of Rights). From the text, it clearly arises that Ethiopia has at the very least the intention to function as a parliamentary federation with constituent nations as its political constituents coexist in a system of symmetric power-relations. Additionally, the Constitution also clearly regulates the process of separation for individual nations within the state one of the key conceptual principles so characteristic to liberal-democratic multinational federations.

\section{The Role of Multination Federalism in Protecting Linguistic Minorities}

In order to alleviate discrimination and oppression against linguistic minorities and protect their interests, some states with different linguistic groups establish multination federalism as a mechanism for accommodating the different interests including that of the linguistic minorities. This is due to the fact that multination federalism grants federal or quasi-federal forms of territorial autonomy to historic sub-state national groups (Kimilka, 2006). In some countries territorial autonomy has been achieved by adopting a federal system since federalism allows the creation of political constituents, controlled by the national minority, with substantial powers of self-government. In other countries, there may be geographic or demographic reasons why federalism in the strict sense will not work. In such cases, quasi-federal forms of territorial autonomy serve as an option (Ibid). So, multination federalism plays a magnificent role in protecting linguistic minorities as it provides the linguistic minorities an opportunity to use their own vernacular language in public institutions such as education, media, parliament and the like, and since it enables them to obtain equal state recognition of their language with that of the majority.

The first role of multination federalism, with which the rest arrangements for the protection of linguistic minorities are linked, is the granting of autonomy to the minority groups. In the contemporary time, federalism is widely accepted as a mechanism for addressing issues of minority groups such as linguistic minorities, and promoting and

${ }^{20}$ The Constitution of Federal Democratic Republic of Ethiopia, Proclamation No. 1/1995, Federal Negarit Gazzeta, No.1, Done at Addis Ababa, $21^{\text {st }}$ August 1995, Article 39. 
protecting their rights through granting certain degree of legislative, judicial and administrative autonomy (Abera, 2008). This enables the minority groups to take control over their own affairs effectively without interference from the centre and to preserve their cultural identity, their customs and traditions as well as their institutions in the way they like (Ibid) in so far as it does not violate the rights and freedoms of others and other accepted limitations. According to Abera Dagafa, normally, claims for autonomy occur where ever a minority group feels that it has been subjected to operation and discrimination in the state where its members live (Ibid). That is, it cannot be claimed in the absence of operation or discrimination. However, we are of opinion that it can also be claimed for the purpose of better protection and promotion of the interests of the minority groups including that of the linguistic minorities. Switzerland can be cited as a good example in this regard as communal autonomy is recognized for the original ethnic and linguistic minorities of French, Italian, German and Romans. The granting of generous local autonomy along with a system of checks and balances between the national assembly and the second chamber representing the canton, is considered to be an important part of a politically system designed to check the majority rule and protect the right of the various ethnic and linguistic groups in a multi-ethnic society like Switzerland. India under article 30 (1) of its Constitution also ensures the autonomy of religious or linguistic minorities to establish and administer educational institutions of their choice.

Another issue relating to minorities involves the preservation and protection of their distinctive characteristics, which is very decisive in the determination of their separate identity (Ibid). This is called the right to identity, which refers to the right of persons belonging to minorities to enjoy their own culture, profess and enjoy their own religion or use their own language (Ibid; Alemante, 2003). However, this may be violated where the Constitutional and political framework of states recognises and protects the cultural identity of the majority dominant group to the exclusion and at the expense of that of the identity of the minority groups. This involves the diffusion of the majority group's language and culture all over the territory of the state through the state institutions (Solomon, 2007). This has negative consequence on the minorities since they are being forced to be assimilated in the realms of the majority language undoubtedly. For instance, when the speakers of one language are assimilated into the realms of other languages against their will, linguistic diversity disappears and the group loses their distinct linguistic identity. Such would be the case when a state prohibits a minority group from using its language in daily intercourse or in schools, or from printing and circulating publications in their own language. The result, in such cases, may not be limited to the loss of identity of a linguistic group, but also may extend to the creation of tensions between competing linguistic groups in a manner detrimental to the unity of a state obviously (Abera, 2008).

In a multination federalism, however, the constituents have been accorded with autonomy to decide on matters pertaining to their affairs. As a result, the minorities have got the opportunity to preserve their interests including their linguistic identity. In order to indicate the potential of multination federalism in allowing linguistic minorities 
to preserve their own languages, Cooter says that, "by having a multiplicity of government, the possibility exists for those governments to carry on their administration in different languages" (Yared, 2009).

Hence, it has moderated the possibility of assimilation and tension between competing linguistic groups by allowing them to live in accordance with their customs and traditions as well as to use their own language. That is, it provides them with an opportunity to preserve and protect their own separate identity. This is not only important for the individual identify but it can also have implications in the realization of other important civil and political rights as well as socio-economic rights (Eide, Krause, \& Rosas, 2001). The Indian Constitution that guarantees the right of linguistic minorities to conserve their own language under article 29 of its Constitution could be a clear manifestation of the role of multination federalism in protecting the right of linguistic minorities to keep their linguistic identity intact.

In addition, the existence of inequalities among different groups in terms of their enjoyment of political rights, political representation and participation has also contribution in the marginalization of minority groups such as linguistic minorities (Solomon, 2007; Khatiwada, 2009). The acontrario reading of this indicates that the participation of minorities in public life has role in the perpetuation of the minorities interest, in view of the fact that it enables persons belonging to a minority to have their legitimate share in the exercise of power; because it will give them the opportunity to influence decisions of the government in case where it is detrimental to their interests (Solomon, 2007). Thus, in order to guarantee the effective participation of members of minorities in public life, it is necessary to have a system that allows the minorities to involve in public life. According to the view of the writer, this is possible by the adoption of a multination federalism; because, first, it allows the minorities to be represented at all the necessary levels of the government. Second, there is territorial devolution of power to the units of the federation, which would extend the opportunities of the minorities in participation of public life including that of public participation. The experience of Switzerland witnesses the political participation of linguistic minorities in the federal council or government and in other federal institutions to a degree exceeding their numerical strength. Power is to be shared by all relevant groups in a cooperative manner, rather than exercised at will by mere 51 percent majority. By use of such a concept, federal institutions and procedures are responsive to the voices from varying groups allowing them to participate in the process of government in an authentic and meaningful way (Thurer, 1995). Although discussions in parliament is held in Hindu or English in India, article 102 (1) of its Constitution in order to ensure the effective participation of linguistic minorities representatives allows any member of the parliament to address the house in his/her mother tongue in case when s/he is not able to adequately express him/herself in Hindu or English.

This territorial devolution of power to the minority including linguistic minorities has the following significance on them: the states and other sub-units would be granted significant levels of autonomy in matters dealing with language, culture and education; 
the system would allow for the emergence of local leaders who strongly identify with the subunits. Such local rooting of political leadership and institutions, even if illusory, tends to satisfy the desire for connective status and recognition among both the rulers and the ruled alike (Alemante, 2003). Thus, it provides them with an internal self-determination, which enables the linguistic minorities to participate in the decision making process of the state on matters affecting their own interests.

Moreover, in pluralistic societies, persons belonging to minorities want to be freed from any distinction, exclusion, restriction, preference based on race, colour, national or ethnic origin, language, religion, birth or any other status which has the purpose or effect of impairing the enjoyment of their fundamental human rights and freedoms. If members of a group having a distinct identity suffer any discrimination as a result of such identity in different fields of public life, it would generate tensions between the majority and the minorities (Solomon, 2007). In order to avoid such tension and provide effective protection to the minorities, the state is required to structure itself in such a way that no particular ethnic, religious or linguistic group is discriminated against (Ibid). Thus, multination federalism has the potential for different groups to be able to live together without necessarily distorting their differences; because it allows every minority groups to maintain their own distinctive identity including language and ensures the right of linguistic minorities by giving their language equal state recognition with that of the linguistic majority. By virtue of this equality, all linguistic groups are entitled to speak, write and develop their respective language.

Furthermore, the issue of education in the minorities' vernacular language is another area for the protection of linguistic minorities. The right to education, especially the right to mother tongue medium of instruction is among the most important rights for any minority, which is one of their traditional demands, since it is a corner stone for their social and economic development (Wondwessen, 2009). They demand this right due to the fact that it is important to preserve their culture and identity. That is, vernacular language serves as an important tool of preserving and enhancing the culture, identity and history of a given minority group. It is also important for the minority child since it would enable them to easily obtain the benefits that the majority would get by learning in their own mother tongue. However, without such right, a minority whose children attend school usually cannot reproduce itself as a minority, which results for forced assimilation to the majority (Solomon, 2007). The role of multination federalism in relation to this right is related to the role of the same in the protection of linguistic minorities so far discussed. Accordingly, the granting of autonomy (internal self-determination), the recognition of their distinctive identity, the assurance of equality and the acceptance of their right to involve in decision makings involving their own affairs, indicates the suitability of multination federalism for enjoyment of the right to education in once own vernacular language. By using all of these grants the minority group can make their own language as a medium of instruction. The use of minority languages in education has got recognition and is practiced in multination states like India, Canada and Ethiopia. The subunits are required to provide primary education 
with the language of various linguistic minorities within their jurisdiction in India. Canada also guarantees minority language education for English and French speaking minorities under section 23 of the Canadian Charter of Rights and Freedoms of 1982. The right provided under the text of section 23 is based on the principle of personality ${ }^{21}$ rather than territoriality ${ }^{22}$ since whenever the minority students number warrant sufficiently to be provided education in their language; it is applicable in every province. In Ethiopia, provision of primary education with the vernacular language of the minorities is being conducted in some regional states like in Amhara, for instance, primary education is provided through "Awigna" and "Afan Oromo" to the speakers of these languages in Awi Zone and Oromia Special Zone respectively, and in Southern Nations, Nationalities and Peoples some nations like Hadiya, Sidama and Wolayita are being taught in their own vernacular language at the primary school.

\section{Conclusions}

In cases where "a sense of national identity and singularity" that demanded a "right to distinct statehood" coincided with the "insuperable difficulties of living alone" and the "practical necessity of sharing the state with neighbouring groups," national independence was either "unattractive or unattainable". Taking "the first law of politics... to start from the facts," one should take difference and diversity for granted in the polity so that "the federal compromise became imperative." And if such a state would always be subject to internal threats of secession, the only way out of this dilemma was "to render what is logically defensible actually undesirable:" "the advantages to the minority group of staying integrated in the whole must on balance be greater than the gain to be reaped from separating." Reason, in other words, would triumph over emotion. In such circumstances, federation was the rational state.

To be specific, multination federalism is munificent enough for the protection of linguistic minorities through the advancement of distinct autonomy in utilizing their own language without any encroachment and arraignment of the majority, insulating their popular participation in the different fields of public life too, in equal footing at the absence of language barrier. It also ensures the linguistic minorities' right to education in their own mother tongue. However, some may argue that it is against the territorial integrity of the state. But, we are of opinion that this argument fails to see the other-sided blowing that has been arising from setting aside the already pre-existing factual realities. Thus, denying the existence of linguistic differences have more negative impacts on the territorial integrity of the state than acknowledging them, so much so that the latter mediates to avoid, demise or minimize the possible tensions that may exist between the linguistic minorities and majorities by respecting and protecting their respective interests.

${ }^{21}$ By "principle of personality," it is to mean that the right to use one's own language that follows the person to claim public service everywhere in the country.

${ }^{22}$ By "Principle of Territoriality", it is to mean that the right of the person to claim the public services in his/her own language, provided the limitation therewith to the territorial coverage, where the language has got recognized as the working language officially i.e. the right is subject to linear geographical limit. 
By and large, language has linear linkage with the quest of identity. Its recognition has been playing superintendent role in keeping status quo of integration tremendously. Obviously, it could reproach what matters in undermining nation building too. This toning the milestone through such channeling, the sense of belongingness will be flying from voluptuous particularism to nationalism flag for the purpose of maintaining the permanent togetherness ultimately. At this juncture, the subject deserves the major practical significance in synthesizing an operative governance system without any fear and tear of backsliding i.e. protecting the linguistic minorities in multi-nation federalism is the. On top of this, it paves a way smooth to cultivate local or traditional skills, knowledge and technology. Accordingly, those local ingredients may have been upgraded to modern requirements of development level, from which their national and international utilities would be brought into line for a common usage beyond board. Such schemes have also been contributing for innovation and creation of a given nation from its traditional discounting to modern scientific and technological furtherance. So does for the national economic development penetratingly. On top of this, it may mitigate the problem of unemployment due to language barrier. Logically speaking, taking cognizance of the language, it could, at least, serve to promote local job opportunity in black and white blatantly. Finally, it is of significance importance in blowing self rule/ administration and tolerance, in wide spreading some democratic virtue and value, in promoting norms, values, taboos etc of that particular group, more often than not. Therefore, it is the tool of social, economic and political lethargy in the multination federalism through illuminating the brightening lesson of common hope and integrity to staying together and dismantling any enrooting threat of disintegration with its vices and evils potentially.

\section{Acknowledgements}

We would like to thank the anonymous reviewers for their important remarks and constructive comments. We are solely responsible for any errors.

\section{References}

Abera, D. (2008). The Scope of Rights of National Minorities under the Constitution of the Federal Democratic Republic of Ethiopia (Vol. 1). Series on Ethiopian Constitutional Law.

Alemante, G. S. (2003). Ethnic Federalism: Its Promise and Pitfalls for Africa. Yale Journal of International Law, 28, 51-107.

Bommes, M., \& Morawska, E. (2005). International Migration Research: Constructions, Omissions and the Promises of Interdisciplinary.

Capotorti, F. (1991). Study on the Rights of Persons Belonging to Ethnic, Religious and Linguistic Minorities. New York: UN.

Convention on the Rights of the Child (1989). Adopted by the UN General Assembly in Resolution No. 44/25 of 20 November 1989 at New York. Entered into Force on 2 September 1990.

Declaration on the Rights of Persons Belonging to National or Ethnic, Religious and Linguistic Minorities (1992). A/RES/47/135 of 18 December 1992, Documents E/CN.4/AC.5/2001/2.

Deschênes, J. (1985). Proposal Concerning the Definition of the Term “Minority”. E/CN.4/Sub.2/ 
$1985 / 31$

Dinstein, Y., \& Tabory, M. (1992). The Protection of Minorities and Human Rights. Leiden: Martinus Nijhoff.

Dosenrode, S. (2010). Federalism Theory and Neo-Functionalism: Elements for an Analytical Framework. Perspectives on Federalism, 2, 1-28.

Eide, A., Krause, C., \& Rosas, A. (2001). Economic, Social and Cultural Rights: A Textbook (2nd ed.). Berlin: Springer.

EU Network of Independent Experts on Fundamental Rights (2005). The Protection of Minorities in the European Union. Thematic Comment No. 3.

European Court of Human Rights (2001). Chapman vs. United Kingdom (Application No. 27238/95).

Human Rights Committee (1990). Chief Bernard Ominayak and the Lubicon Lake Band vs. Canada, Communication No. 167/1984 (UN Doc. Supp. No. 40 (A/45/40).

Human Rights Committee (1993). Ballantyne, Davidson, McIntyre vs. Canada, Communications Nos. 359/1989 and 385/1989 (CCPR/C/47/D/359/1989 and 385/1989/Rev. 1.

Human Rights Committee (1994). The Rights of Minorities, General Comment No. 23.

Human Rights Committee (1997). Hopu and Bessert vs. France, Communication No. 549/1993 (CCPR/C/60/D/549/1993/Rev.1).

Human Rights Committee (2006). Concluding Observations, Canada (CCPR/C/CAN/CO/5).

ICESCR (1976). Adopted and Opened for Signature Ratification and Accession by the General Assembly of the UN, Resolution 2200 XXI of 16 December 1966: Entry into Force on 3 January 1976.

ILO Convention concerning Indigenous and Tribal Peoples in independent countries (ILO Convention No. 169 ILO official Bulletin 59 (1991).

International Crisis Group (ICG) (2009). Ethiopia: Ethnic Federalism and its Discontents. Africa Report No. 153.

Joseph, G. (1991). Protection of Language Rights in International Human Rights Law: A Proposed Draft Declaration of Linguistic Rights. Virginia Journal of International Law, 32, 515579.

Khatiwada, A. (2009). Linguistic Minorities: Issues in their Rights and Protection.

Kimilka, W. (2006). Emerging Western Models of Multination Federalism: Are They Relevant for Africa? In D. Turton (Ed.), Ethnic Federalism: The Ethiopian Experience in Comparative Perspective (pp. 32-64). Athens, OH: Ohio University Press.

Kugelmann, D. (2007). The Protection of Minorities and Indigenous Peoples Respecting Cultural Diversity. In A. von Bogdandy, \& R. Wolfrum (Eds.), Max Planck Year Book of UN Law (Vol. 11, pp. 233-263). Periodic Publications of the Institute.

Leuprecht, P. (2001). Minority Rights Revisited. In P. Alston (Ed.), Peoples' Rights (pp. 111-123). Oxford: Oxford University Press.

Musgrave, T. (1997). Self-Determination and National Minorities. Oxford: Oxford University Press.

Palermo, C. F., \& Woelk, J. (2003/4). From Minority Protection to a Law of Diversity? Reflections on the Evolution of Minority Rights. In European Year Book of Minority Issues (pp. 5-13). Leiden: Martinus Nijhoff Publishers.

Permanent Court of International Justice (1935). Minority Schools in Albania (Greece vs. Albania), Orders and Advisory Opinion, PCIJ. Series A/B, Judgements No. 64. 
Plant, R. (1994). Land Rights and Minorities. London: MRG.

Rehman, J. (2000). The Weaknesses in the International Protection of Minority Rights. Hague: Kluwer Law International.

Riker, W. H. (1964). Federalism: Origin, Operation and Significance. Boston: Brown and Company.

Scheinin, M., \& Toivanen, R. (2004). Rethinking Non-Discrimination and Minority Rights. Turko/Abo: Institute for Human Rights of Abo Akamedi University and Berlin: German Institute for Human Rights.

Simpson, A. W. B. (2001). Human Rights and the End of Empire. Oxford: Oxford University Press.

Singo'ei, K. (2003). Kenya's Untouchables: The Nubians' Struggle for Recognition of Their Rights. Briefing Paper, Nairobi: Centre for Minority Rights Development.

Solomon A. D. (2007). The Protection of Minorities under the African Charter: Opportunities and Challenges. Paper Presented at the Conference of Johannesburg on Organization of Justice and Protection of Fundamental Rights in South Africa organized by UNISA and Centre for European Constitutional Law.

The Constitution of Federal Democratic Republic of Ethiopia (1995). Proclamation No. 1/1995.

Thornberry, P. (1991). International Law and the Rights of Minorities. Oxford: Clarendon Press.

Thurer, D. (1995). National Minorities: A Global, European and Swiss Perspective.

Trim, J. (2002). Linguistic Diversity: A Challenge for European Cities and Regions, Proceedings, Rovinj (Croatia), 22-23 March 2001. Studies and Texts No.74, Strasbourg: Council of Europe Publishing.

Trudeau, P. (1968). Federalism and the French Canadians. Toronto: MacMillan.

UDHR (1948). Adopted by the General Assembly of the UN, Resolution 217 (III) of 10 December 1948.

Wiessner, S. (2005). Demographic Change and the Protection of Minorities.

Wondwessen, H. (2009). The Protection of Minority Nationalities under the Federal Democratic Republic of Ethiopia Constitution: An Overview. Addis Ababa: Addis Ababa University Press.

Yared, L. (2009). Linguistic Regimes in Multinational Federations: The Ethiopian Experience in a Comparative Perspective (Vol. 2). Ethiopian Constitutional Law Series, Addis Ababa: Addis Ababa University Press. 
Submit or recommend next manuscript to SCIRP and we will provide best service for you:

Accepting pre-submission inquiries through Email, Facebook, LinkedIn, Twitter, etc. A wide selection of journals (inclusive of 9 subjects, more than 200 journals)

Providing 24-hour high-quality service

User-friendly online submission system

Fair and swift peer-review system

Efficient typesetting and proofreading procedure

Display of the result of downloads and visits, as well as the number of cited articles

Maximum dissemination of your research work

Submit your manuscript at: http://papersubmission.scirp.org/

Or contact blr@scirp.org 